\title{
Substantiation and process design to manufacture polymer-concrete transfer cases for mining machines
}

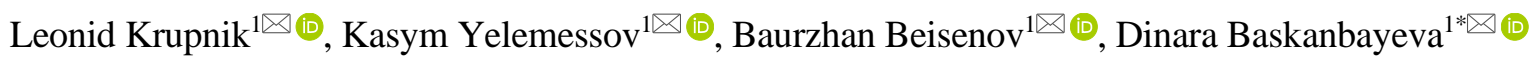 \\ ${ }^{1}$ Institute of Metallurgy and Industrial Engineering, Satbayev University, Almaty, 50013, Kazakhstan \\ *Corresponding author: e-mail baskanbaeva@mail.ru, tel.+380123456789
}

\begin{abstract}
Purpose. To determine efficient polymer-concrete composition and to develop a process design to use the material to manufacture transfer cases for mining machines operating under very heavy conditions to improve their strength, durability, and operational economy.

Methods. Compositions of polymer-concrete being tested have been applied to manufacture models being the bars with $40 \times 40$ section and $160 \mathrm{~mm}$ length. The models were produced by series in threes by means of the mixture placing in the special metal moulds. A sample of the polymer-concrete mixture to manufacture the models was taken from the central share of the batch. The polymer-concrete mixture was placed and compacted within the moulds in accordance with the regulatory requirements. To accelerate solidification, the models were warmed-up in a drier at $80^{\circ} \mathrm{C}$ temperature. Strength tests of the solidified models were performed using hydraulic press PGM-50MG4 according to regulatory requirements.

Findings. Technological capability and expediency of the polymer concrete use to manufacture transfer cases operating under heavy conditions have been identified. The material has a number of advantages: less weight of the product, high strength and resistance to corrosive media. Methods of the efficient portioning of such a polymer-concrete mixture have been developed; stress-strain properties of the mixture after solidification have been defined; effect of rotational speed of the mixer effector and mixing time on the production of the mixer having homogenous characteristics. Transfer case TS-250 has been manufactured and tested which demonstrated positive results.

Originality. New regularities of the effect of temperature of initial components, rotational speed of the mixer effector, and plastifier consumption on the polymeric-concrete mixture have been identified. The abovementioned is required for the development of efficient method to manufacture transfer case components.

Practical implications. Optimum composition of polymeric-concrete mixture has been developed; parameters of the method and operation modes of mixture formation and transfer component casting have been tested. Such castings of transfer cases were produced which supported performance capabilities and efficiency of the process solutions.
\end{abstract}

Keywords: polymer concrete, transfer case, aggregate, resin, hardener, rotational speed, silagerm, casting, homogenous mixture, isotropic material

\section{Introduction}

The current stage of industrial revolution 4.0 is characterized by a wide use of innovative structural materials providing durability of technical products, simplification of their production methods, and cost saving. Nowadays, the world practices apply extensively certain techniques for the manufacturing of different machine and mechanism components using new structureal materials with the improved stress-strain properties [1]-[4]. Polymer concrete, being one of the most promising materials, is rather popular in the construction industry [5]-[8]. The material is characterized by high strength, processibillity, and resistance to corrosive media. However, the world practices have no information concerning the material use in machine-building industry.
That is why the Department of Production Machines and Equipment of Satbayev Kazakh National Technical University (Satbayev University) carried out research to develop a method for the production of polymer-concrete transfer cases for machines operating at the enterprises of mining and metallurgical complex. The facilities act under such heavy conditions as corrosive medium, high or low temperatures, dustiness, and watering inclusive of other factors impacting durability of their transfer cases.

Currently, transfer cases are made of thicker metal. They are characterized by complex production and maintenance technology. Analysis of the equipment has shown that each metallurgical enterprise uses numerous transfers; thus, modernization of their cases by means of substitution of materials they are made of is a topical problem. 
Transfer cases are their basic components intended to:

- place and provide the required allocation of parts and nodes of the transfer gears;

- take loads, acting within the transfer, and transmit it to a subrtansfer plate or frame;

- organize a system to lubricate working surfaces of gear wheels and bearings of the transfer;

- protect parts and nodes of the transfer gear from their pollution by environmental foreign particles;

- prevent the lubricant, used in the transfer, against its environmental discharge (in the process of the transfer operation).

Case parts are the most metal-intensive ones. Up to $80 \%$ of the whole product mass belongs to them. Their hugeness and complex shape complicate significantly manufacturing process of the parts.

Mainly, shape of transfer cases is determined by mutual arrangement of the parts and nodes of the transfer gear mechanisms, the requirements of their manufacturing technology, operation, and design. Strength and stiffness requirements are also involved. Cases, which box-type structure is based upon plane surfaces and cylindrical surfaces, are the most popular since they are easy to be manufactured.

\subsection{Analysis of scientific source data and statement of the problem}

Steady production growth and industrial use of composite materials [9], [10] support the concept that demand for them, embodied progressive ideas and techniques, is a very high demand. Specific features of composites predetermined their role among construction materials and for the purposes of machine-building industry. Construction industry prefers composites solidifying with the help of a cold-cold procedure, i.e. with no extra power consumption. Such a technique to produce composites is described by numerous studies. Their analysis shows that as a rule, epoxide, polyether, and carbamide resins are applied for their production [11], [12].

Plastic binder-based composites are promising for their application in the corrosion medium making it possible to find them expedient for their use in the context of machinebuilding industry.

Determination of the efficient mixture compositions with the specified properties is one of the topical tasks aimed at the wide use of the composites [13].

During the process of the arising problem solving, it is possible to single out two aspects: material-science aspect and technological one. The former is to identify quantitative and qualitative connection between aggregate, filler, and binders of the polymer-concrete mixture. The latter concerns production method of the mixture, and its use to manufacture parts and components of machines and mechanisms. A model of a polymer-concrete mixture, being considered as a complex material system, is the methodological foundation to solve the problems [14]-[16]. The abovementioned makes it possible to evaluate comprehensively a role of each component as well as the effect of their complex on properties of the polymer-concrete mixture and its products.

Formation of the polymer concrete structure and its qualitative characteristics takes place at the stages of selection of the mixture components, their blending to obtain homogenic material, and the product solidification. In this context, operation mode of each specific stage should provide the required quality of the product according to a system of operational characteristics [17], [18].
Hence, the analysis has demonstrated that the current method to produce polymer concrete and its products is based upon certain principles: optimization of granulometric composition of aggregate and filler as well as their quality; use of definite mofifiers (i.e. plasticizers, surface-active substances etc.); and provision of the efficient structurization conditions. That guarantees the specified quality of polymer concrete products.

\subsection{Objective of the activities and the research tasks}

Objective of the research is to determine efficient polymer-concrete composition and to develop a method of transfer case production on its basis.

Achievement of the objective should involve solving the problems:

- determination of the efficient materials and a method to manufacture polymer concrete with the required characteristics;

- development of a technique for the polymer-concrete mixture preparation to cast transfer-case components;

- elaboration of a method to cast transfer-case components using the polymer concrete.

\section{Methodology}

Implementation of the objectives involved the use of the integrated research methodology covering a number of the specific methodologies.

Theoretical studies of the polymer-concrete mixture were carried out to substantiate the necessity of three-fractional composition of aggregate and filler as well as their dependence in terms of fractional size and quantity within the mixture amount. Further, the findings were supported experimentally in a laboratory environment.

The compositions of polymer-concrete mixtures, being tested, were used to make models being bars with $40 \times 40 \mathrm{sec}-$ tion and $160 \mathrm{~mm}$ length. The models were produced by the series in threes by means of the mixture placing in the special metal moulds. A sample of the polymer-concrete mixture to manufacture the models was taken from the central share of the batch. The polymer-concrete mixture was placed and compacted within the moulds in accordance with GOST 101802012 requirements. To accelerate solidification, the models were warmed-up in a drier at $80^{\circ} \mathrm{C}$ temperature.

Strength of the solidified samples was tested with the help of a hydraulic press PGM-50MG4 according to GOST 101802012 requirements. To compensate spatial deviation from possible nonparallelism of bearing faces of the sample, the press was equipped with a movable ball pivot. First, the samples were tested by bending; then, halves of the bars were tested by compression. Minimal result was not taken into consideration of the three obtained results; the two remaining ones were applied to determine a mean value according to the GOST. The research helped specify efficient composition of the polymer concrete and identify its stress-strain properties.

Decision-making concerning a technique to produce transfer case components, using casting, involved engineering study of a moulding tool. Its idea is as follows: the analysis has shown that the cast should take into consideration a number of factors differing greatly from the classic metal casting. First, it is the material to produce the casts. Second, its design should provide high reliability and ease of fabrication and assembly. And, the last but not least, 
the cast should be convenient to take the moulded product out witout its possible damage.

Several mould models with the use of various materials were casted and tested which helped select the best alternatives. They were applied in the process of further research.

The problems were solved wholistically during the research which made it possible to propose the final method.

Following specific demands were placed on the polymer concrete to produce transfer cases using casting: after its preparation, the mixture should be characterized by homogenous properties to provide further qualitative product casting; after solidification, the products will be characterized by perfect isotropic properties.

High strength of the solidified mixture should be provided as well as its preservation for the whole operation period of the product.

Moreover, such a polymer-concrete mixture should be cost-efficient to compete with the metals used traditionally for transfer case production.

Our research made it possible to identify efficient composition of polymer concrete for its effective use to produce transfer case components (Table 1).

Table 1. Characteristics of the recommended composition of polymer concrete to cast transfer case components

\begin{tabular}{lccc}
\hline Components & $\begin{array}{c}\text { Content, } \\
\%\end{array}$ & $\begin{array}{c}\text { Ultimate compression } \\
\text { strength, } \delta_{c}, \mathrm{MPa}\end{array}$ & $\begin{array}{c}\text { Ultimate bending } \\
\text { strength } \delta_{b}, \mathrm{MPa}\end{array}$ \\
\hline Rubble & 51.0 & & \\
Quartz sand & 25.5 & & \\
Quartz flour & 11.0 & & \\
Resin & 10.5 & $165-167$ & $58-60$ \\
Solidifying & 2.0 & & \\
agent & & & \\
Total & 100.0 & & \\
\hline
\end{tabular}

In terms of the minimum consumption of the components, samples of the polymer concrete are of high compression strength and high bending strength providing long-term operation of the transfers under severe operating conditions.

The composition of polymer concrete is characterized by following characteristics. Its aggregate consists of three fractions: rubble, quartz sand, and quartz flour differing by an order of magnitude in terms of their granulometric compositions. Fine fractions fill cavities in larger fractions making it possible to produce a high-density mixture while improving its strength characteristics after solidifying. Moreover, such a mixture needs less solidifying agent reducing drastically the cost of the polymer-concrete mixture.

Since the factors, effecting polymer concrete characteristics, are numerous, prevailing factors have been selected and their importance has been evaluated according to regression coefficients of a linear model. The abovementioned helped plan the amount of the experiments to achieve optimum area across lots. In this context, a response surface methodology by Box and Wilson has been applied [19], [20].

A step for each factor has been selected to minimize the number of the experiments. The abovementioned has considered that small steps may prevent from recording of changes in the optimization parameters lengthening the search, and upper step boundary is limited by the area of the factor determination. In this context, the movement was performed from the experiment centre (i.e. basic level) to its periphery (i.e. upper and bottom levels).

\section{The results}

\subsection{Determination of efficient composition of the polymer-concrete mixture}

Polymer concretes are innovative chemically stable materials which mineral filling and aggregating rate achieves 90-95\% of their mass. The new materials cannot compete with other compositions as for the plastic binder consumption being only $5-10 \%$ of total mass of the polymer concrete. Naturally, its cost is minimized. In terms of the comparatively minor consumption of a plastic binder per a mass unit, polymer concretes are of high density, strength, chemical stability, and other positive characteristics. In this context, high filling rate makes it possible to decrease shrinkage sharply, which becomes equal to the cement concrete shrinkage, and increase elasticity coefficient significantly making it possible to apply such concretes for load bearing structures and rather critical ones. Thus, it is possible to give evidence of the polymer concrete potential to compare with metals.

The analysis has helped define that temperature of fillers and aggregates, speed rate of component mixing, and plastifier amount within the mixture are the most important factors effecting strength characteristics in the process of polymer concrete preparation.

Figures 1,2 and 3 demonstrate the experimental results after their statistical processing.

The research has demonstrated that adherence to a technology of preparing of basic materials as well as mixing mode of the components is among the key factors providing stability of polymer concrete characteristics.

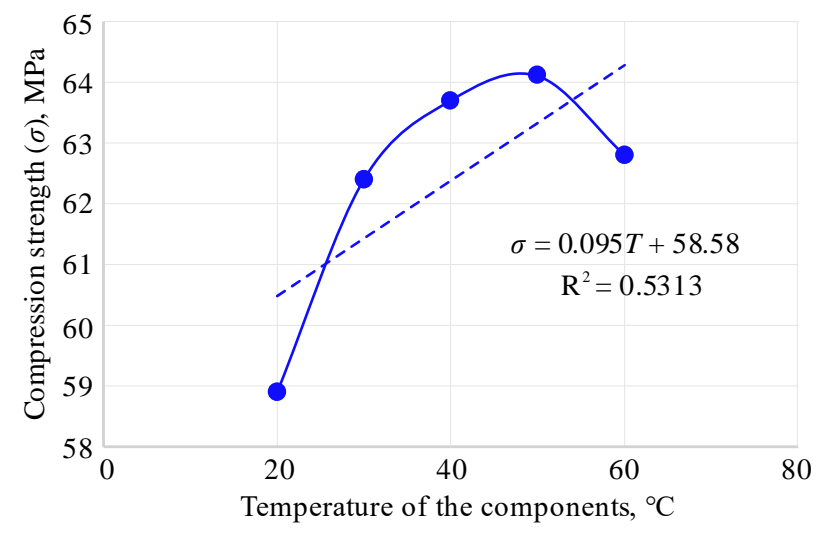

Figure 1. Effect of the component temperature on the polymer concrete strength

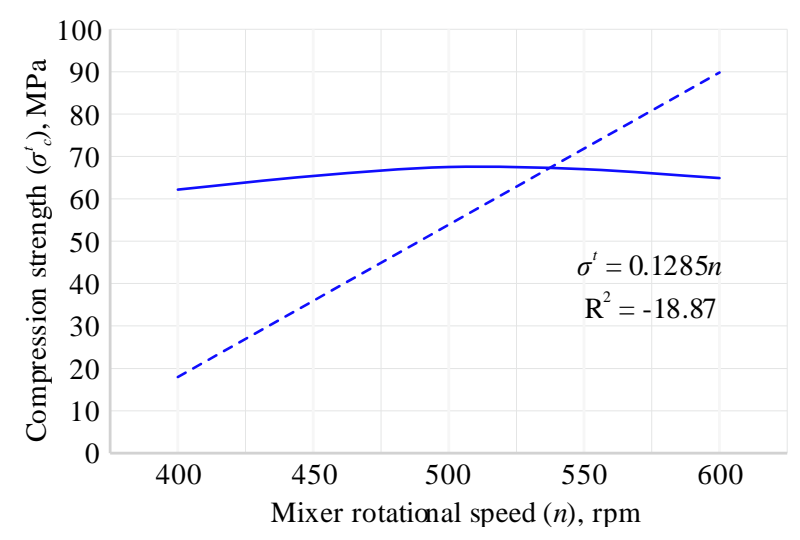

Figure 2. Effect of rotational speed of a mixer effector on the polymer concrete strength 


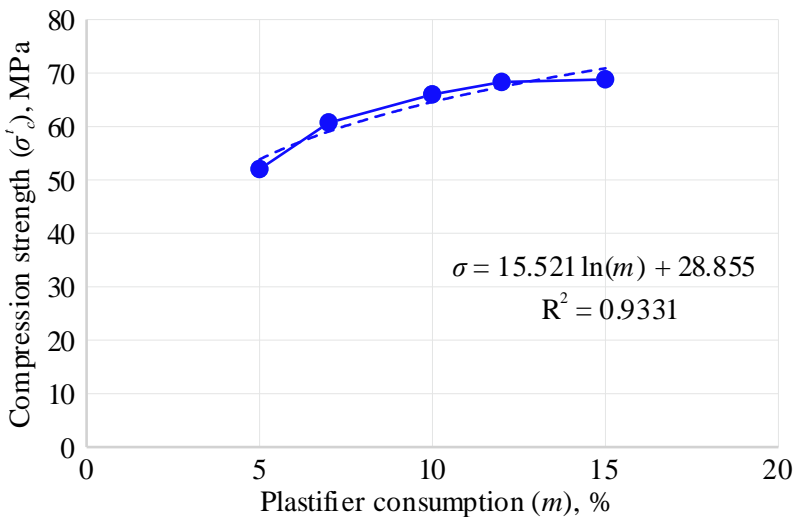

Figure 3. Plastifier consumption effect on the polymer concrete strength

It has been identified that 2-stage polymer-concrete mixture preparation is the efficient technique. Stage one is a filling preparation with the use of a high-speed mixer. Stage two is mixing of three aggregate fractions to which the filling is added. Then the mixture is brought into a ready mix state.

Development of a method to cast upper transfer cover and lower one, using the polymer-concrete mixture, was a following stage of the research.

\subsection{Results of determination of efficient technique for the production of transfer case components}

Despite the differences in shapes and sizes, transfer case components have the common structural elements: the pieced walls, lugs, ribs, and sockets.

Since transfer cases are traditionally low-stress parts, sizes of their components (i.e. thickness of walls, lugs etc.) are determined mainly by stiffness, required to provide performance capabilities of kinematic pairs of the transfer (i.e. gears, bearings etc.), rather than by the strength. The required stiffness is achieved by the optimized shape and dimensions of the case components as well as by means of the efficient placement of reinforcement ribs.

For the sake of convenient assembling of parts and transmission nodes, the majority of transfers are manufactured as disconnectable ones within the axial planes of transfer shafts. Then, such a case consists usually of two case parts: lower part, called a casing, and upper one called a casing cover (Fig. 4).

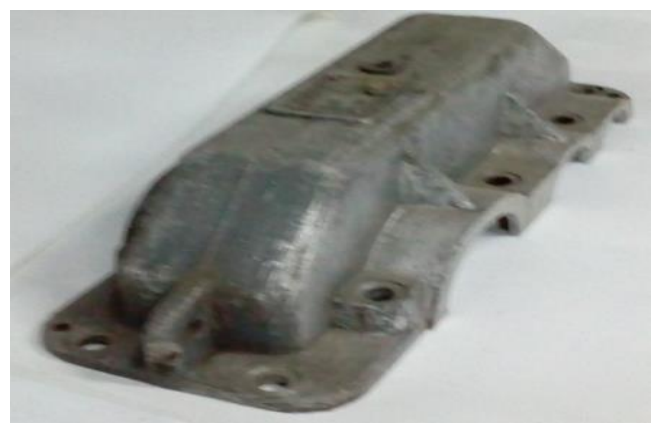

Figure 4. Casing cover

Availability of the division reduces structural stiffness, increases production cost (the matter is that case components, being mated within the surface divisions should be processed clearly and accurately; holes for fastening parts are required), and needs extra expenditures connected with the supporting members of the case parts to be mated (i.e. bolts, screws etc.). at the same time, the division helps separate each transfer shaft inclusive of all pieces located on it (i.e. tooth wheels, bearings, distance sleeves etc.) into the independent structure which is assembled and controlled early regardless of other shafts. Then, in the process of final assembly of a transfer, it is installed easily in the transfer case.

Results of the analysis and experiments have helped determine that it is the most expedient idea to apply sheet steel of 0.5-0.6 mm thickness, and angle elements \#4 to manufacture master forms while casting polymer-concrete products since they are quite usable in the process of contact welding to join them. Selection of a material to shape external surface and internal surface of the master form is very important procedure. It is connected directly with a mode of casting of parts and their picking out of the master form after solidification, i.e. when they are ready to be used. Casting silicone Silagerm 7140 has been applied. Its characteristics are:

- shore hardness number (A), 35-45;

- apparent viscosity of the compound (cPs), 10000-250000;

- rupture resistance $(\mathrm{MPa}), 2.0-3.5$;

- tear strength $\left(\mathrm{MPa} / \mathrm{m}^{2}\right), 0.01-0.015$;

- tension strain 200-250.

Silagerms of 7000 class are silicones solidified by tin compounds on the principle of polycondensation. They are of high rupture strength, high stability, and operational lifetime.

To fix the silicone master form at a frame surface, sheetsteel arrows are spotwelded at the one-third height from the upper edge of the frame shape at a $100 \mathrm{~mm}$ pitch (Fig. 5).

(a)

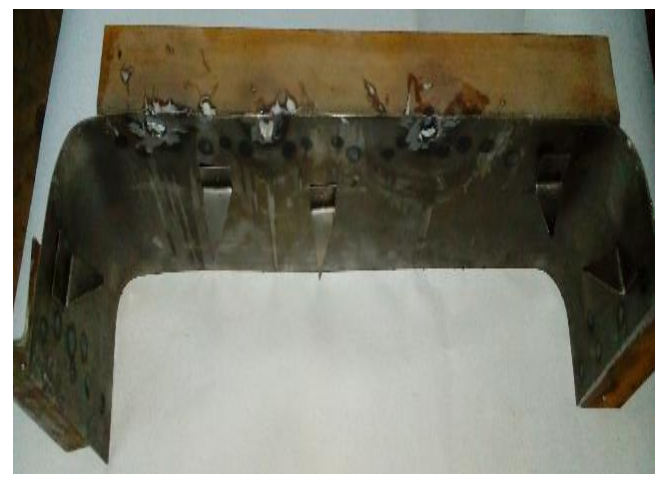

(b)

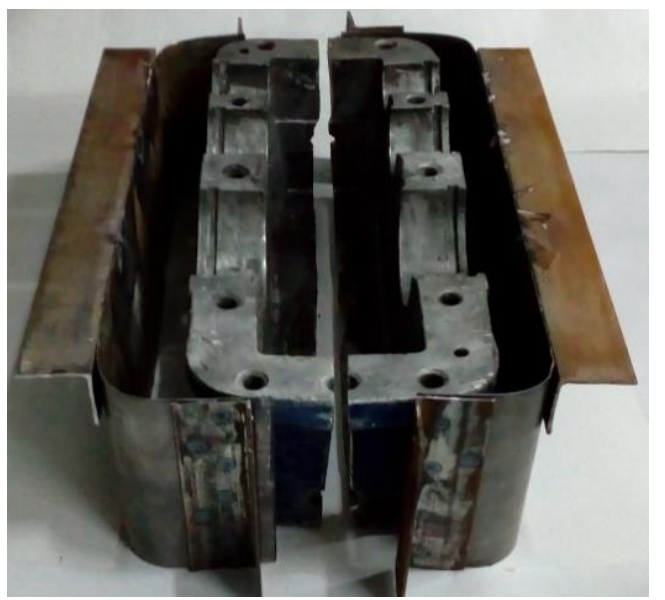

Figure 5. Frame of a transfer cover shape: (a) end view; (b) geneal view 
Silagerm 7140 solidifies at room temperature during 24 hours. It is applied to produce shapes with complicated configuration. Shore hardness number 35-45 A helps preserve the shape geometry in terms of volume huge filling. Its operational thermal mode is -60 to $+250^{\circ} \mathrm{C}$. The characteristics meet completely casting requirements of large-size transfer components which was supported by the research.

If top casting takes place then the arrows on the frame prevents polymer concrete from it its getting between silicone master from and the frame. After the frame division, the master form can be separated easily from the external surface of a cover by means of its dismantling from the arrows.

Following procedure for a master form manufacture has been proposed relying upon the research results. Steel pipes with $1 / 2^{\prime \prime}$ diameter are laid down along the axis of bearing housings and welded against each other for the internal surface, and upper and lower covers of the transfer case.

Hence, the amount of silicone being filled is reduced. The structure is fixed at the internal surface of covers by means of the fingers installed in the frame holes. It works for upper cover and for lower cover. After installation, internal cavity is filled up by casting silicone.

However, to remove the mould from the transfer stand, having hollows (Fig. 6), it should be sawn down, and separating plate should be installed between the frame halves (Fig. 7). Silicone has to be filled from the lower part of the stand by reversing the frame and putting it at a vibrating table surface (Fig. 8). Hence, the research has helped design the efficient master form corresponding to the polymer concrete features; its production method has been proposed.

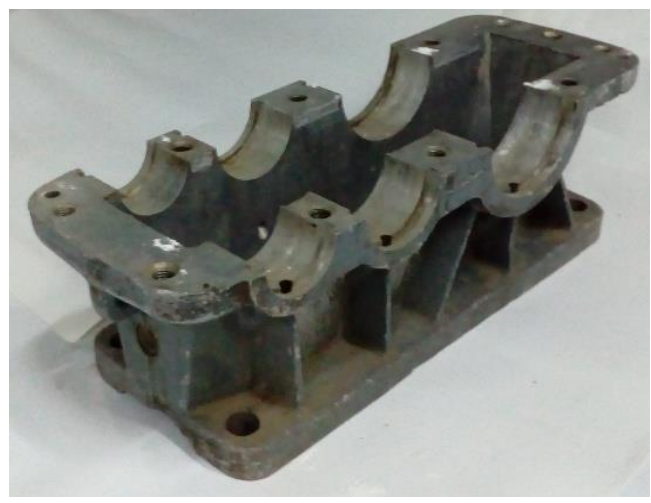

Figure 6. Transfer stand

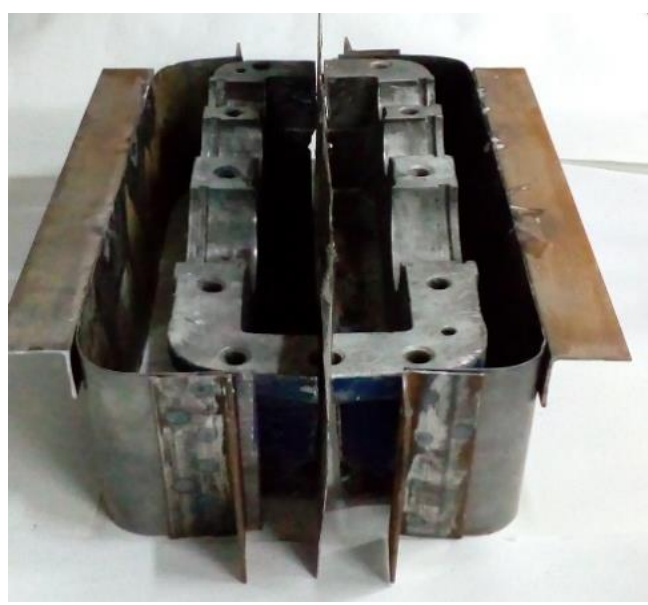

Figure 7. Separating plate installation into a transfer stand frame

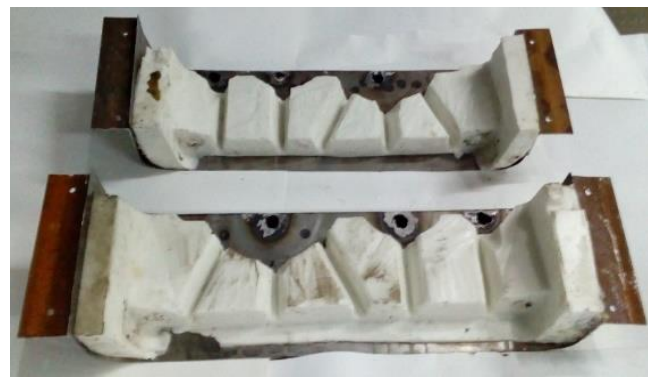

Figure 8. Moulds for a transfer stand casting

The method takes into consideration specific characteristics of the polymer-concrete mixture and provides the end product picking out of a master form leaving the product undamaged. The method has been piloted under the laboratory conditions, and supported its performance capabilities. The proposed composition of polymer concrete was applied to cast lower and upper covers of TS-250 transfer. The components need not any further additional processing; they are almost ready to be used.

\section{Discussion}

The research has demonstrated that adherence to a technology of preparing of basic materials as well as mixing mode of the components is among the key factors providing stability of polymer concrete characteristics.

It has been identified that it is expedient to prepare polymer-concrete mixture during several stages.

Stage one is preparation of input products. Humidity of aggregates and fillers should not exceed 0.5-1\% since strength of a polymer concrete as well as its other characteristics get worse is wet aggregate is applied. The trouble is that the thinnest water layer on the aggregate particles degrades solidification of polymeric binder reducing its adhesion to them. Thus, aggregates and fillers should be dried up at $80-110^{\circ} \mathrm{C}$ temperature with their mandatory cooling down to standard $20+5^{\circ} \mathrm{C}$ temperature before batching.

Dose accuracy is quite important to obtain stable predictable stress-strain properties of polymer concrete:

- resin, filler, and solidifying agent $- \pm 1 \%$ by weight;

- aggregate $- \pm 2 \%$ by weight.

Preparation of the polymer-concrete mixture should involve following operations: screening of aggregates, preparation of solidifying agents, proportioning, and mixing.

Stage two is mastic compounding. The procedure is as follows:

- the dosed resin and plastifying agent are fed to a high-speed mixture with their following mixing during 10-12 seconds;

- adding of the dosed aggregate to the mixture with following mixing during 30-60 seconds;

- adding of the dosed solidifying agent to the mixture with following mixing during 30 seconds; and

- mastic discharging from the operating mixture to a concrete-mixing machine during 25-30 seconds.

Hence, the total time for mastic preparation should not exceed 100 seconds; taking into consideration discharging process, the period should not be more than two minutes.

Adding resin share to a tank with aggregates is required to originate thin resin films at the surface of aggregates. In this context, following mastic adding will not result in resin absorption from the binder. Strength of contact layers of the 
latter will not decrease as it happens when a binder is added to the processed aggregate.

Stage three involves preparation of the polymer-concrete mixture itself. The procedure is:

- charge of aggregates and their blending in a concretemixing machine during 1-2 minutes;

- mastic, prepared at the previous stage, is fed to a concrete-mixing machine;

- the polymer-concrete mixture is conditioned during 4-5 minutes;

- the polymer-concrete mixture is discharged from the concrete-mixing machine to moulds should be performed during 30-6 seconds.

Such a multistage mixture preparation has a number of advantages:

- the total period of mixing cycle is reduced as well as resin consumption;

- a binder is more uniform in terms of its composition. It can be ether warmed up or cooled down in the process to control its viscosity and life. Moreover, it is possible to vacuuming is also applicable for deaeration and strength improvement.

Due to a short life of polymer-concrete mixtures, they should be placed right after mixing. Otherwise, the large amount of heat, developed in the process of resin-solidifying agent interaction, may factor into rapid self-heating of the mixture resulting in the accelerated resin solidification and early setting-up of the mix.

Mixing of all the components should be performed at 500$600 \mathrm{~min}^{-1}$ rotational speed of the mixer effector. Such an operation mode for a polymer-concrete mixture preparation makes it possible to obtain a homogenous combination with uniform distribution of all the components helping to obtain isotropic solidified mix with similar characteristics in each its point.

Relying upon rheological characteristics of the proposed polymer-concrete mixture, efficient design of a master form has been developed and materials for its production have been selected. While product forming, vibrating table with overfrequency for vibrocompaction should be used for casting of case parts owing to higher viscosity and adhesiveness of polymer-concrete mixture. The proposed method is in a full accord with polymer cement features providing picking out of transfer case components from a master form undamaged.

Thus, the proposed method of polymer-cement mixture preparation as well as the technique to cast transfer case components using the product is more preferable to compare with the current alternatives. The advantages are as follows: simplicity and reliability; economic efficiency; and the guarantee to obtain the scheduled characteristics.

It should be noted that use of the proposed method to manufacture case components for other equipment, on which special demands are placed, will require further research concerning composition of polymer-concrete mix, its preparation modes, and casting of parts.

\section{Conclusions}

The research has demonstrated that in terms of its characteristics, the polymer concrete is able to replace a metal as for the transfer case component production. Moreover, it has a number of advantages: less product weight, high strength, and resistance to corrosion media.

The proposed composition of polymer-concrete mix is characterized by high density providing substantial strength increase after solidification, and cost effectiveness.
The proposed method for the mix preparation makes it possible to produce homogenous mixture while providing isotropy of a material after its solidification.

The developed technique to manufacture transfer case parts provides their production with no additional mechanical processing.

\section{Acknowledgements}

The research was carried out within the framework of the grant financing project of the Republic of Kazakhstan for the years of 2018-2020 "Transport facilities, farm machinery, oil and gas equipment, and mining and metallurgical equipment. Applied research" in the field of AP 05131236 "Modernization of mining and metallurgical equipment with the use of innovative materials and drive arrangement".

\section{References}

[1] Kang, H.S., Lee, J.Y., Choi, S., Kim, H., Park, J.H., \& Son, J.Y. Noh, S.D. (2016). Smart manufacturing: Past research, present findings, and future directions. International Journal of Precision Engineering and Manufacturing-Green Technology, 3(1), 111-128. https://doi.org/10.1007/s40684-016-0015-5

[2] $\mathrm{Xu}, \mathrm{X}$. (2017). Machine Tool 4.0 for the new era of manufacturing. The International Journal of Advanced Manufacturing Technology, 92(5-8), 1893-1900. https://doi.org/10.1007/s00170-017-0300-7

[3] Kolosov, D., Bilous, O., Tantsura, H., \& Onyshchenko, S. (2018). Stress-strain state of a flat tractive-bearing element of a lifting and transporting machine at operational changes. Solid State Phenomena, (277), 188-201. https://doi.org/10.4028/www.scientific.net/ssp.277.188

[4] Vlasova, E., Kovalenko, V., Kotok, V., \& Vlasov, S. (2016). Research of the mechanism of formation and properties of tripolyphosphate coating on the steel basis. Eastern-European Journal of Enterprise Technologies, 5(5(83)), 33-39. https://doi.org/10.15587/1729-4061.2016.79559

[5] Koblischek, P.J. (1991). Polymer concrete as an alternative material for grey cast iron and welded steel construction in the machine tool industry. Brittle Matrix Composites, (3), 529-538. https://doi.org/10.1007/978-94011-3646-4_56

[6] Jain, A. (2012). Polymer concrete: Future of construction industry. International Journal of Scientific Research, 2(11), 201-202. https://doi.org/10.15373/22778179/nov2013/64

[7] Jo, B.W., Park, S.K., \& Kim, D.K. (2008). Mechanical properties of nano-MMT reinforced polymer composite and polymer concrete. Construction and Building Materials, (1), 14-20.

[8] Wongpa, J., Kiattikomol, K., Jaturapitakkul, C., \& Chindaprasirt, P. (2010). Compressive strength, modulus of elasticity, and water permeability of inorganic polymer concrete. Materials \& Design, 31(10), 4748-4754. https://doi.org/10.1016/j.matdes.2010.05.012

[9] Goryacheva, V.A., Kreshchik, A.A., Khristoforova, I.A., \& Khristoforov, A.I. (2015). Sovremennoe sostoyanie proizvodstva polimerbetonov. Mezhdunarodnyy Studencheskiy Nauchnyy Vestnik, (3-2), 230-231.

[10] Khristoforov, A.I., Khristoforova, I.A., Guyumzhdyan, P.P., \& Glukhoedov, V.V. (2004). Polimerbeton na osnove polivinilkhloridnogo svyazuyushchego. Izvestiya VUZov. Khimiya $i$ Khimicheskaya Tekhnologiya, 47(1), 159-160.

[11] Solomatov, V.I. (2004). Tekhnologiya polimerbetonov $i$ armopolimerbetonnykh izdeliy. Moskva, Rossiya: Nauka.

[12] Babin, L.O. (2000). Prognozirovanie mekhanicheskikh svoystv polimerbetonov. Avtoreferat dissertatsii. Lipetsk, Rossiya: Lipetskiy gosudarstvennyy tekhnicheskiy universitet.

[13] Krupnik, L., Yelemessov, K., Bortebayev, S., \& Baskanbayeva, D. (2018). Studying fiber-reinforced concrete for casting housing parts of pumps. Eastern-European Journal of Enterprise Technologies, 6(12(96)), 22-27. https://doi.org/10.15587/1729-4061.2018.151038

[14] Figovsky, O., \& Beilin, D. (2013). Advanced polymer concretes and compounds. London, United Kingdom: CRC Press, Taylor \& Francis Group. https://doi.org/10.1201/b16237

[15] Petrov, N., \& Baskanbayeva, D. (2018). Reliability estimate of technical systems containingcomposite materials through analysis of the concurrent risks. International Journal of Scientific Engineering and Research, 6(10), 54-56.

[16] Khristoforov, A.I., Guyumdzhyan, P.P., Khristoforova, I.A., \& Glukhoedov, V.V. (2004). Vliyanie sposoba zalivki na plotnost' betonov s silikatnym zapolnitelem. Stroitel'nye Materialy, Oborudovanie $i$ Tekhnologii XXI Veka, (4), 52-53. 
[17] Baskanbayeva, D., Yelemessov, K., \& Igbayeva, A. (2019). Gearbox bodies made of polymer concrete for mining and metallurgical complex. In Materials of the $2^{\text {nd }}$ International Scientific and Technical Internet Conference "Innovative Development of Resource-Saving Technologies of Mineral Mining and Processing”, 204-207.

[18] Krupnik, L., Yelemesov, K., Beisenov, B., Sarybaev, E., \& Baskanbayeva, D. (2018). Use of air bellows for low-speed drive mechanisms.
International Journal of Scientific \& Engineering Research, 9(11), 1106-1112.

[19] Barabash, D.E. (2000). Primenenie matematicheskikh metodov planirovaniya eksperimentov dlya optimizatsii sostava polimerbetonov. Voronezhskiy TsNTI, (137), 1-6.

[20] Adler, Yu.T., Markova, E.V., \& Granovskiy, Yu.V. (1976). Planirovanie eksperimenta pri poiske optimal'nykh usloviy. Moskva, Rossiya: Nauka.

\section{Обгрунтування та розробка технології виготовлення корпусів редукторів 3 полімербетону для гірничих машин}

\section{Л. Крупник, К. Єлемесов, Б. Бейсенов, Д. Басканбаєва}

Мета. Вишукування раціонального складу полімербетону та розробка технології виготовлення з нього корпусів редукторів гірничих машин, що працюють у важких умовах, для підвищення їх міцності, зносостійкості та економічності.

Методика. 3 випробуваних складів полімербетонних сумішей виготовлялися зразки - балочки перетином $40 \times 40$ і довжиною 160 мм. Зразки виготовлялися серіями по три зразки шляхом укладання суміші в спеціальні металеві форми. Проба полімербетонної суміші для виготовлення зразків відбиралася з середньої частини замісу. Укладання та ущільнення полімербетонної суміші у формах здійснювалось відповідно до нормативних вимог. Для прискореного твердіння зразки у формах прогрівалися в сушильній шафі при температурі $80^{\circ} \mathrm{C}$. Випробування отверділих зразків на міцність здійснювалися на гідравлічному пресі ПГМ-50МГ4 відповідно нормативним вимогам.

Результати. Встановлено технічну можливість і доцільність використання полімербетону для виготовлення корпусів редукторів, які працюють в складних умовах, що має ряд переваг: меншу масу виробу, високу міцність та стійкість до агресивних середовищ. Розроблено методику підбору раціонального складу полімербетонних сумішей, визначено їх фізико-механічні характеристики після затвердіванняння, виявлено вплив частоти обертання робочого органу змішувача і часу перемішування на отримання суміші, що має гомогенні властивості. Виготовлений і випробуваний корпус редуктора Ц-250, який показав позитивний результат.

Наукова новизна. Встановлено нові закономірності впливу на характеристики полімербетонної суміші температури вихідних компонентів, частоти обертання робочого органу змішувача й витрати пластифікатора для розробки раціональної технології виготовлення корпусних деталей редукторів.

Практична значимість. Розроблено оптимальний склад полімербетонної суміші, перевірено параметри і режими технології сумішоутворення та виливки елементів редукторів. Отримано виливки корпусів редукторів, які підтвердили працездатність та ефективність запропонованих технологічних рішень.

Ключові слова: полімербетон, корпус редуктора, заповнювач, смола, затверджувач, частота обертання, сілагерм, лиття, гомогенна суміш, ізотропний матеріал

\section{Обоснование и разработка технологии изготовления корпусов редукторов из полимербетона для горных машин}

\section{Л. Крупник, К. Елемесов, Б. Бейсенов, Д. Басканбаева}

Цель. Изыскание рационального состава полимербетона и разработка технологии изготовления из него корпусов редукторов горных машин, работающих в сложных условиях, для повышения их прочности, износостойкости и экономичности.

Методика. Из испытуемых составов полимербетонных смесей изготавливались образцы - балочки сечением $40 \times 40$ и длинной 160 мм. Образцы изготавливались сериями по три образца путем укладки смеси в специальные металлические формы. Проба полимербетонной смеси для изготовления образцов отбиралась из средней части замеса. Укладку и уплотнение полимербетонной смеси в формах производили в соответствии с нормативными требованиями. Для ускоренного отвердевания образцы в формах прогревались в сушильном шкафу при температуре $80^{\circ} \mathrm{C}$. Испытания отвердевших образцов на прочность осуществлялись на гидравлическом прессе ПГМ-50МГ4 в соответствии с нормативными требованиями.

Результаты. Установлена техническая возможность и целесообразность использования полимербетона для изготовления корпусов редукторов, работающих в сложных условиях, и имеющего ряд преимуществ: меньшую массу изделия, высокую прочность и стойкость к агрессивным средам. Разработана методика подбора рационального состава полимербетонных смесей, определены их физико-механические характеристики после отвердения, выявлено влияние частоты вращения рабочего органа смесителя и времени перемешивания на получение смеси, имеющей гомогенные свойства. Изготовлен и испытан корпус редуктора Ц-250, показавший положительный результат.

Научная новизна. Установлены новые закономерности влияния на характеристики полимербетонной смеси температуры исходных компонентов, частоты вращения рабочего органа смесителя и расхода пластификатора. Это необходимо для разработки рациональной технологии изготовления корпусных деталей редукторов.

Практическая значимость. Разработан оптимальный состав полимербетонной смеси, отработаны параметры и режимы технологии смесеобразования и отливки элементов редукторов. Получены отливки корпусов редукторов, подтвердившие работоспособность и эффективность предложенных технологических решений.

Ключевые слова: полимербетон, корпус редуктора, заполнитель, смола, отвердитель, частота вращения, силагерм, литье, гомогенная смесь, изотропный материал

\section{Article info}

Received: 16 August 2019

Accepted: 7 May 2020

Available online: 15 May 2020 